\title{
Article \\ Offretite Zeolite Single Crystals Synthesized by Amphiphile-Templating Approach
}

\author{
Eng-Poh $\mathrm{Ng}^{1, *(\mathbb{D})}$, Nur Hidayahni Ahmad ${ }^{1}$, Fitri Khoerunnisa ${ }^{2}$, Svetlana Mintova ${ }^{3}$ (D), Tau Chuan Ling ${ }^{4}$ \\ and T. Jean Daou $5,6, *$ (D)
}

check for updates

Citation: Ng, E.-P.; Ahmad, N.H.; Khoerunnisa, F.; Mintova, S.;

Ling, T.C.; Daou, T.J. Offretite Zeolite Single Crystals Synthesized by Amphiphile-Templating Approach. Molecules 2021, 26, 2238. https:// doi.org/ 10.3390/molecules26082238

Academic Editor: Sergio Navalon

Received: 30 March 2021

Accepted: 9 April 2021

Published: 13 April 2021

Publisher's Note: MDPI stays neutral with regard to jurisdictional claims in published maps and institutional affiliations.

Copyright: (c) 2021 by the authors. Licensee MDPI, Basel, Switzerland. This article is an open access article distributed under the terms and conditions of the Creative Commons Attribution (CC BY) license (https:// creativecommons.org/licenses/by/ $4.0 /)$.
1 School of Chemical Sciences, Universiti Sains Malaysia, Penang 11800 USM, Malaysia; nurhidayahni@gmail.com

2 Department of Chemistry, Universitas Pendidikan Indonesia, Setiabudi 229, Bandung 40154, West Java, Indonesia; fitri@upi.edu

3 Laboratoire Catalyse et Spectrochimie (LCS), Normandie Université, ENSICAEN, UNICAEN, CNRS, 14050 Caen, France; mintova@ensicaen.fr

4 Institute of Biological Sciences, Faculty of Science, University of Malaya, Kuala Lumpur 50603, Malaysia; tcling@um.edu.my

5 Institut de Science des Matériaux de Mulhouse (IS2M), CNRS, Axe Matériaux à Porosité Contrôlée (MPC), Université de Haute-Alsace (UHA), 3 bis rue Alfred Werner, 68093 Mulhouse, France

6 Université de Strasbourg, 67000 Strasbourg, France

* Correspondence: epng@usm.my (E.-P.N.); jean.daou@uha.fr (T.J.D.)

\begin{abstract}
Offretite zeolite synthesis in the presence of cetyltrimethylammonium bromide (CTABr) is reported. The offretite crystals were synthesized with a high crystallinity and hexagonal prismatic shape after only $72 \mathrm{~h}$ of hydrothermal treatment at $180^{\circ} \mathrm{C}$. The CTABr has dual-functions during the crystallization of offretite, viz. as structure-directing agent and as mesoporogen. The resulting offretite crystals, with a $\mathrm{Si} / \mathrm{Al}$ ratio of 4.1 , possess more acid sites than the conventional offretite due to their high crystallinity and hierarchical structure. The synthesized offretite is also more reactive than its conventional counterpart in the acylation of 2-methylfuran for biofuel production under non-microwave instant heating condition, giving $83.5 \%$ conversion with $100 \%$ selectivity to the desired product 2-acetyl-5-methylfuran. Hence, this amphiphile synthesis approach offers another cost-effective and alternative route for crystallizing zeolite materials that require expensive organic templates.
\end{abstract}

Keywords: hierarchical zeolites; crystal growth; offretite zeolite; amphiphile-templating approach; acylation of 2-methylfuran

\section{Introduction}

Zeolites are crystalline microporous materials made up of tetrahedral $\mathrm{TO}_{4}(\mathrm{~T}=\mathrm{Si}$ or Al) repeating units [1]. These porous solids are widely used in catalysis, separation, and ion exchange processes due to their unique structure with defined size and shape [2-4]. Currently, 253 types of zeolite structures have been recognized by the International Zeolite Association (IZA) [5]. The synthesis of zeolites can be performed by using various techniques such as organo-templating [6,7]; organotemplate-free [8,9]; ionothermal [10,11]; interconversion [12,13]; assembly, disassembly, organization, and reassembly (ADOR) [14,15]; and fluoride routes [16,17].

Offretite zeolite (OFF topology) has a 3-dimensional channel system containing 12membered rings with a diameter $6.7 \times 6.8 \AA^{2}$. It is considered a very important zeolite due to its large pore size, which allows ease of molecular diffusion and accessibility [18]. To our knowledge, offretite can only crystallize in the presence of tetramethylammonium $\left(\mathrm{TMA}^{+}\right)$as a structure-directing agent (SDA) and both $\mathrm{NaOH}$ and $\mathrm{KOH}$ as mineralizers [19]. However, this zeolite seldom crystallizes completely free from erionite (ERI) and analcime (ANA) intergrowth, making the synthesis of pure OFF phase a challenge [20]. 
Recently, a new strategy for synthesizing offretite has been reported using new SDAs, such as pyrocatechol [21] and $p$-dioxane [22]. The resulting crystals possess different morphologies (oval, hexagonal, broccoli-like, prismatic) with merely microporosity due to the unique properties (e.g., size, shape, polarity, etc.) of the SDAs. Furthermore, offretite can also be readily crystallized via inter-zeolite conversion method using benzyltrimethylammonium hydroxide as an organic template, but the method is complicated and produces a small amount of erionite as a competing phase [23].

In the present work, we applied a combined rational strategy to synthesize large offretite single crystals with hierarchical porosity using a cationic amphiphile template (cetyltrimethylammonium bromide, CTABr), whereas this template is normally used for the synthesis of MCM-41 mesoporous materials [24-26]. By using CTA ${ }^{+}$cation, the hydrophilic head of the amphiphile serves as an SDA for the growth of the zeolite while its hydrophobic tail generates mesoporosity, allowing the formation of hierarchical zeolite (micro/mesoporosity). It should, therefore, have superior adsorption and catalytic properties to the conventional offretite.

\section{Results and Discussion}

Initially, the crystallization of offretite was carried out at $180{ }^{\circ} \mathrm{C}$ for $40 \mathrm{~h}$. The XRD results revealed that the solid product remained amorphous after $40 \mathrm{~h}$, and the synthesis time was extended to $72 \mathrm{~h}$. The amorphous solid completely transformed into offretite zeolite, and no other crystalline phase, such as erionite or merlinoite, was co-crystallized (Figure $1 b)$. The XRD pattern of offretite synthesized using $\mathrm{CTA}^{+}\left(\mathrm{CTA}^{+}\right.$-offretite) corresponded to the simulated one, and a difference in the XRD peaks intensity of $\mathrm{CTA}^{+}$-offretite due to the preferred crystal orientation was observed (Figure 1a,c) [27]. The crystallization process was also performed in the absence of CTABr. However, pure LTL-type zeolite was obtained, showing the significant role of the $\mathrm{CTA}^{+}$in directing the formation of offretite zeolite.

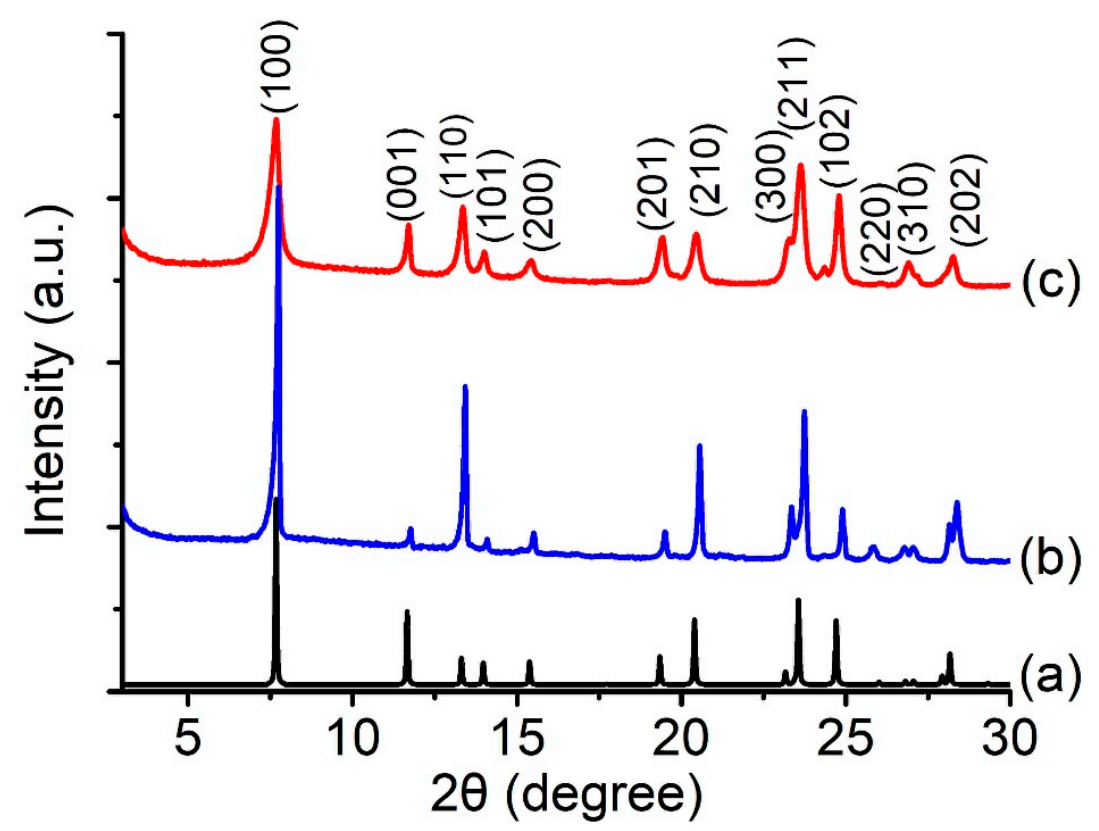

Figure 1. XRD patterns of (a) offretite (simulated pattern), (b) cetyltrimethylammonium $\left(\mathrm{CTA}^{+}\right)$offretite and (c) tetramethylammonium $\left(\mathrm{TMA}^{+}\right)$-offretite zeolites.

The SEM images of offretite crystals prepared using amphiphile templating route are shown in Figure 2a,b. As seen, this method successfully produced offretite single crystals with a hexagonal prismatic shape (inset of Figure $2 \mathrm{a}$ ). The surface of $\mathrm{CTA}^{+}$ offretite crystals at $a$ - and $b$-directions were smooth, indicating that the crystals were grown along the $c$-direction [19], forming crystals of $10.8 \times 1.4 \mu \mathrm{m}^{2}$ length with an as- 
pect ratio of 7.7. Interestingly, the morphology of the crystals was different from that of classical TMA ${ }^{+}$-offretite zeolite, which exhibits a rice-grain-shape (ca. $4.6 \times 3.4 \mu \mathrm{m}^{2}$ ) composed of intergrown acicular primary nanocrystals (ca. $880 \times 79 \mathrm{~nm}^{2}$ ) (Figure $2 \mathrm{c}, \mathrm{d}$ ). The smaller crystallite size of $\mathrm{TMA}^{+}$-offretite is the reason for the XRD peak broadening [28] (Figure 1c).
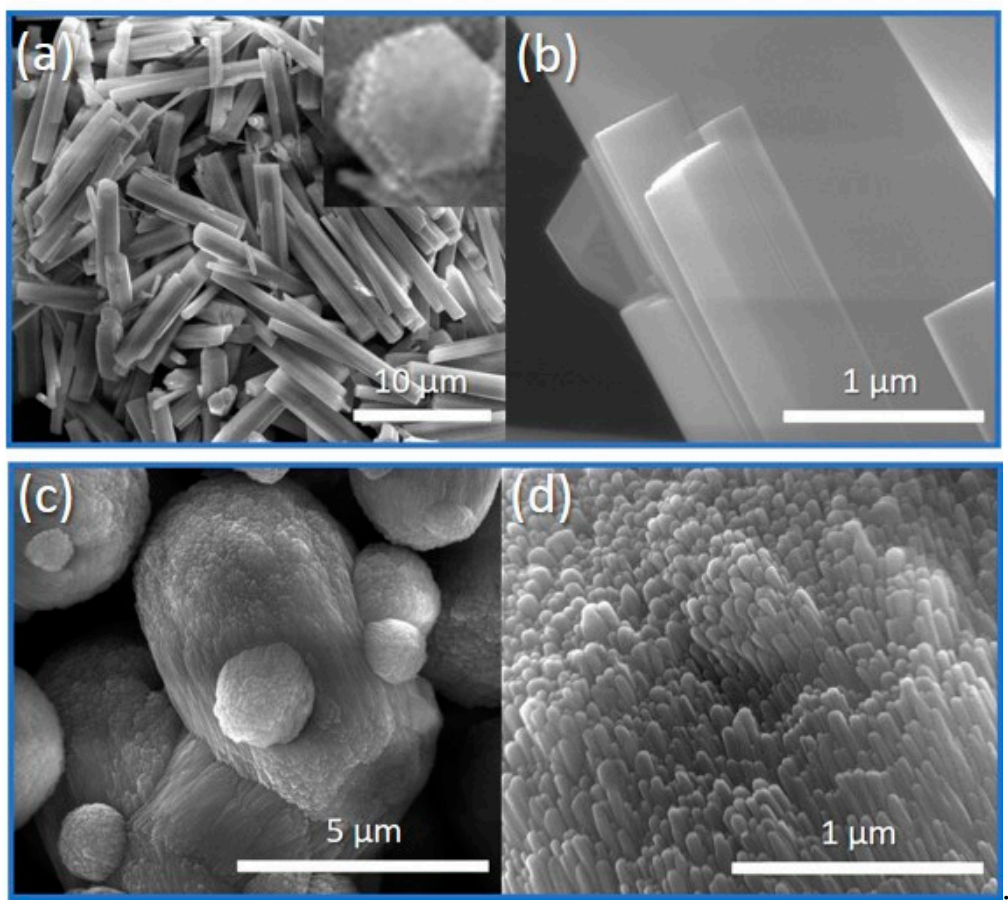

Figure 2. SEM images of $(\mathbf{a}, \mathbf{b}) \mathrm{CTA}^{+}$-offretite and $(\mathbf{c}, \mathbf{d}) \mathrm{TMA}^{+}$-offretite zeolites under different magnifications.

Offretite zeolite is an interesting catalyst due to its large pore size and considerably high $\mathrm{Si} / \mathrm{Al}$ ratio ( $>3)$. According to the IR spectroscopy analysis, the $\mathrm{Si} / \mathrm{Al}$ ratio of $\mathrm{CTA}^{+}-$ offretite zeolite is 4.1. The molecular formula for the $\mathrm{CTA}^{+}$-offretite is calculated to be $\mathrm{K}_{3.4} \mathrm{Al}_{3.4} \mathrm{Si}_{14} \mathrm{O}_{36}$, which is very close to that of $\mathrm{TMA}^{+}$-offretite synthesized in the presence of $\mathrm{KOH}$ and $\mathrm{NaOH}$ mineralizers $\left(\mathrm{Na}_{1.7} \mathrm{~K}_{1.7} \mathrm{H}_{0.6} \mathrm{Al}_{4} \mathrm{Si}_{14} \mathrm{O}_{36}, \mathrm{Si} / \mathrm{Al}=3.50\right)$ and the theoretically predicted one $\left(\mathrm{Na}_{0.2} \mathrm{~K}_{0.9} \mathrm{Al}_{4} \mathrm{Si}_{14} \mathrm{O}_{36}, \mathrm{Si} / \mathrm{Al}=3.50\right)$ (Table 1) [5]. The textural properties of both $\mathrm{CTA}^{+}$-offretite and $\mathrm{TMA}^{+}$-offretite were studied using nitrogen adsorption-desorption analysis. The calcined $\mathrm{CTA}^{+}$-offretite solid exhibited a combination of type I and IV adsorption isotherms, indicating the presence of micro- and mesoporosities in the solid [29] (Figure 3a). As a result, multimodal pore size distribution was shown due to the role of $\mathrm{CTA}^{+}$as a mesoporogen, as well as acting as structure-directing agent for the formation of offretite zeolite (inset of Figure 3a). The $\mathrm{CTA}^{+}$-offretite also had higher specific surface area $\left(\mathrm{S}_{\mathrm{BET}}=523 \mathrm{~m}^{2} / \mathrm{g}\right)$, micropore surface area $\left(\mathrm{S}_{\mathrm{Mic}}=503 \mathrm{~m}^{2} / \mathrm{g}\right)$, mesopore volume $\left(\mathrm{V}_{\text {Meso }}=0.05 \mathrm{~cm}^{3} / \mathrm{g}\right)$, and total pore volume $\left(\mathrm{V}_{\text {tot }}=0.26 \mathrm{~cm}^{3} / \mathrm{g}\right)$ as compared to the conventional TMA ${ }^{+}$-offretite zeolite $\left(\mathrm{S}_{\mathrm{BET}}=504 \mathrm{~m}^{2} / \mathrm{g}\right.$, $\mathrm{S}_{\text {Mic }}=491 \mathrm{~m}^{2} / \mathrm{g}, \mathrm{V}_{\text {Meso }}=0 \mathrm{~cm}^{3} / \mathrm{g}$, $\mathrm{V}_{\mathrm{Tot}}=0.19 \mathrm{~cm}^{3} / \mathrm{g}$ ), which strongly supports the high crystallinity of $\mathrm{CTA}^{+}$-offretite zeolite (Figure 3b).

Table 1. Properties of offretite zeolites.

\begin{tabular}{|c|c|c|c|c|c|c|c|c|c|c|}
\hline \multirow[b]{2}{*}{ Samples } & \multirow[b]{2}{*}{ Si/Al } & \multirow{2}{*}{$\begin{array}{l}\mathrm{S}_{\mathrm{BET}} \\
\left(\mathrm{m}^{2} / \mathrm{g}\right)\end{array}$} & \multirow{2}{*}{$\begin{array}{c}\mathrm{S}_{\mathrm{Mic}} \\
\left(\mathrm{m}^{2} / \mathrm{g}\right)\end{array}$} & \multirow{2}{*}{$\begin{array}{c}S_{\text {Ext }} \\
\left(\mathrm{m}^{2} / \mathrm{g}\right)\end{array}$} & \multirow{2}{*}{$\begin{array}{l}V_{\text {Meso }} \\
\left(\mathrm{cm}^{3} / \mathrm{g}\right)\end{array}$} & \multirow{2}{*}{$\begin{array}{c}V_{\text {Tot }} \\
\left(\mathrm{cm}^{3} / \mathrm{g}\right)\end{array}$} & \multicolumn{4}{|c|}{$\mathrm{NH}_{3}$-TPD Acidity $(\mathrm{mmol} / \mathrm{g})$} \\
\hline & & & & & & & $\begin{array}{r}T_{\text {des, }} \\
150{ }^{\circ} \mathrm{C} \\
\end{array}$ & $\begin{array}{r}T_{\text {des, }} \\
200^{\circ} \mathrm{C} \\
\end{array}$ & $\begin{array}{r}\mathrm{T}_{\text {des, }} \\
350^{\circ} \mathrm{C}\end{array}$ & Total \\
\hline $\mathrm{CTA}^{+}$-offretite & 4.1 & 523 & 503 & 20 & 0.05 & 0.26 & 0.18 & 0.24 & 0.32 & 0.74 \\
\hline $\mathrm{TMA}^{+}$-offretite & 3.5 & 504 & 491 & 13 & 0 & 0.19 & 0.17 & 0.26 & 0.25 & 0.68 \\
\hline
\end{tabular}




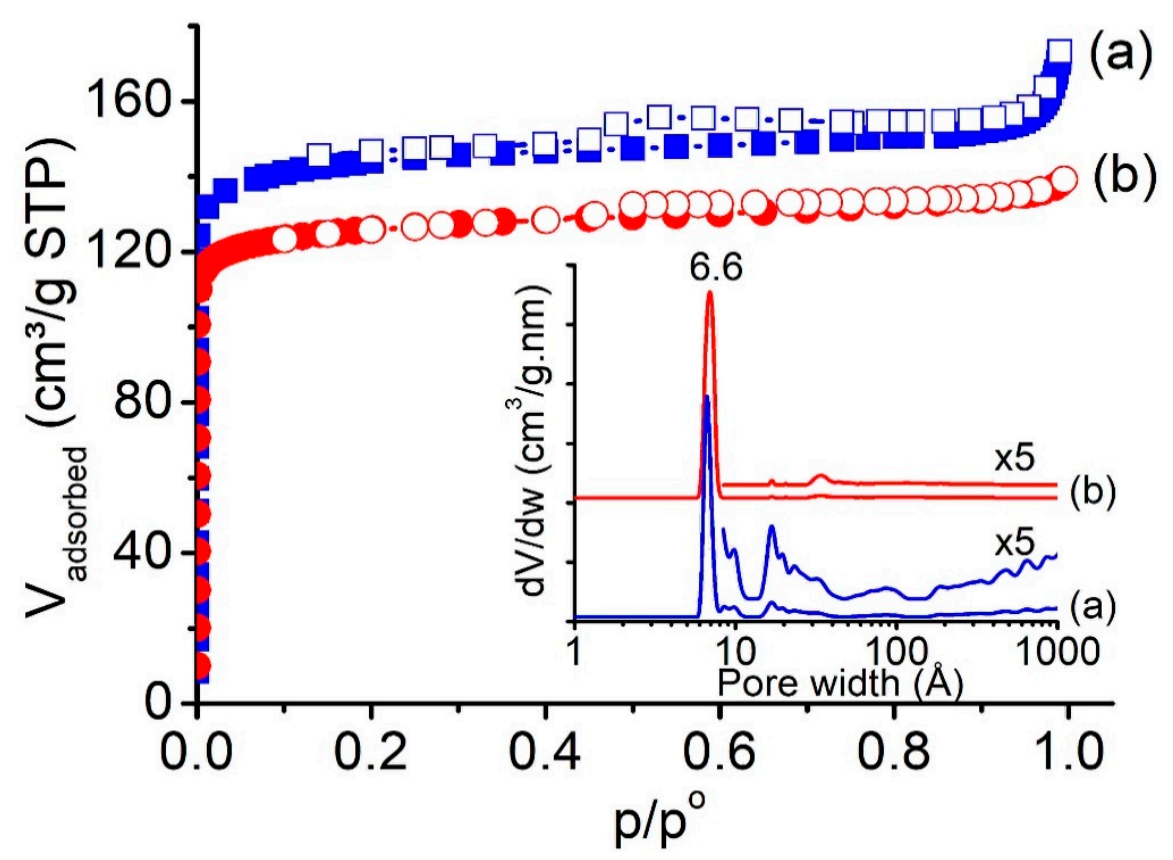

Figure 3. Nitrogen adsorption-desorption isotherms and (inset) pore size distributions of (a) $\mathrm{CTA}^{+}-$ offretite and (b) $\mathrm{TMA}^{+}$-offretite zeolites.

It is suggested that $\mathrm{CTA}^{+}$has a dual function in the crystallization of $\mathrm{CTA}^{+}$-offretite. First, the trimethylamine group $\left(\mathrm{R}-\mathrm{N}\left(\mathrm{CH}_{3}\right)_{3}{ }^{+}, 4.26 \times 2.99 \AA^{2}\right.$ [30]) of $\mathrm{CTA}^{+}$, which has nearly similar molecular size/dimensions to $\mathrm{TMA}^{+}\left(\mathrm{N}_{(}\left(\mathrm{CH}_{3}\right)_{4}{ }^{+}, 4.25 \times 3.70 \AA^{2}\right.$ [30]), directs the formation of OFF framework structure via restricted electrostatic interaction with the silicoaluminate anionic oligomers (Figure 4). The inorganic intermediate species then enfold the $\mathrm{CTA}^{+}$hydrophilic head, thus, inducing nucleation points for long-range propagation and crystallization of offretite zeolite. Secondly, the $\mathrm{CTA}^{+}$cation also serves as a porogen by forming irregular micelles, whereby the hydrophobic tails point to each other, leading to the formation of mesopores of wide distribution [31].

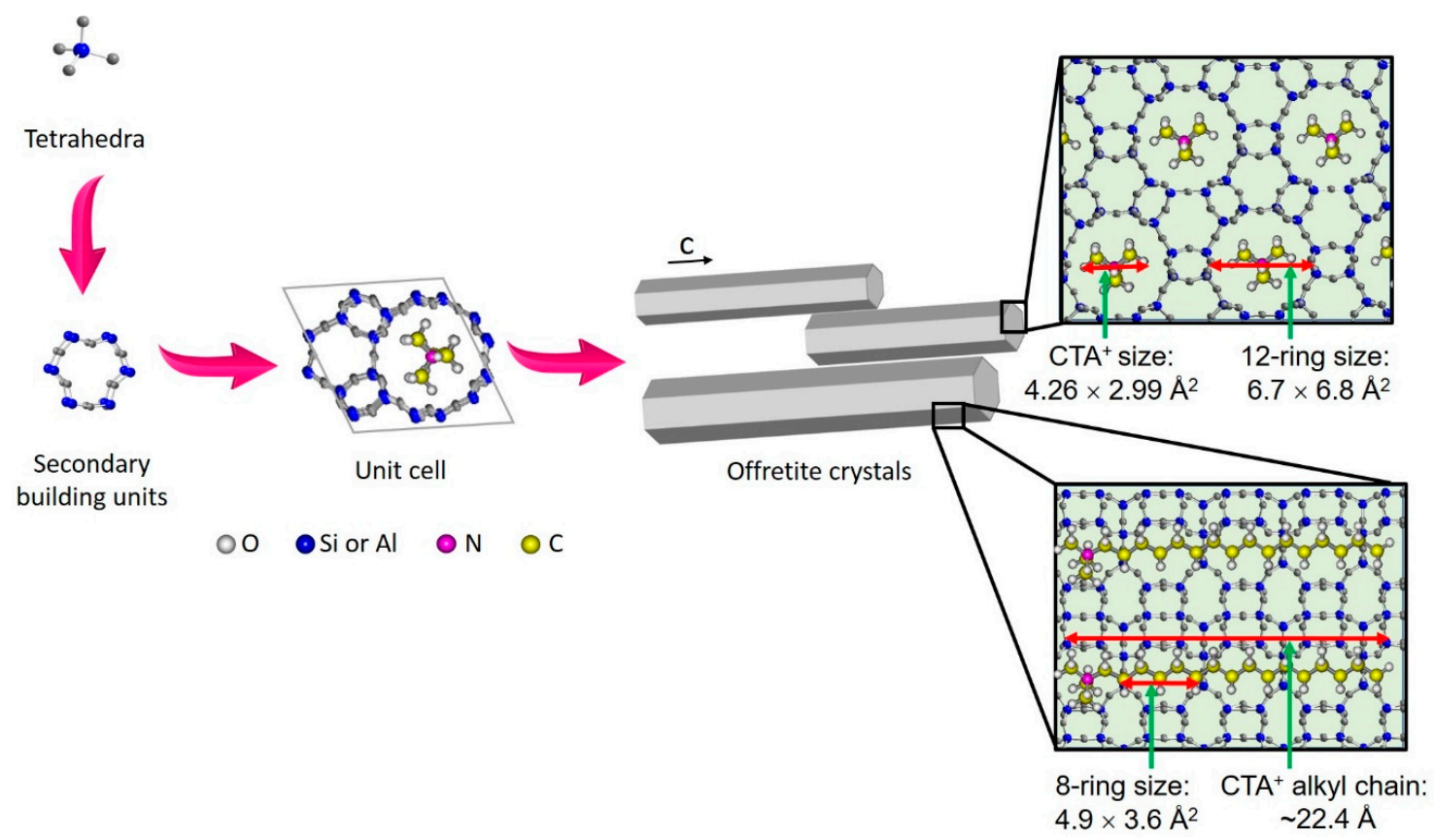

Figure 4. Formation mechanism of offretite zeolite templated by $\mathrm{CTA}^{+}$cations $\left(\mathrm{K}^{+}\right.$cations are not shown for simplicity). 
The calcined $\mathrm{CTA}^{+}$-offretite had surface acidity after converting into protonated form (Figure 5). Hence, $\mathrm{NH}_{3}$-TPD analysis was used to study the acidity of the zeolite samples. As shown, both the $\mathrm{CTA}^{+}$- and $\mathrm{TMA}^{+}$-offretites had a nearly similar number of weak $\left(\mathrm{T}_{\mathrm{des}, 1500^{\circ} \mathrm{C}}=0.18 \mathrm{mmol} / \mathrm{g}\right)$ and mild $\left(\mathrm{T}_{\mathrm{des}, 200^{\circ} \mathrm{C}}=0.25 \mathrm{mmol} / \mathrm{g}\right)$ acid sites. Nevertheless, the $\mathrm{CTA}^{+}$-offretite contained a much larger number of strong acid sites $\left(\mathrm{T}_{\text {des }, 350}{ }^{\circ} \mathrm{C}=0.32 \mathrm{mmol} / \mathrm{g}\right)$ than the $\mathrm{TMA}^{+}$-offretite $(0.68 \mathrm{mmol} / \mathrm{g})$, which could be due to its higher crystallinity and larger accessibility due to the hierarchical structure [32].

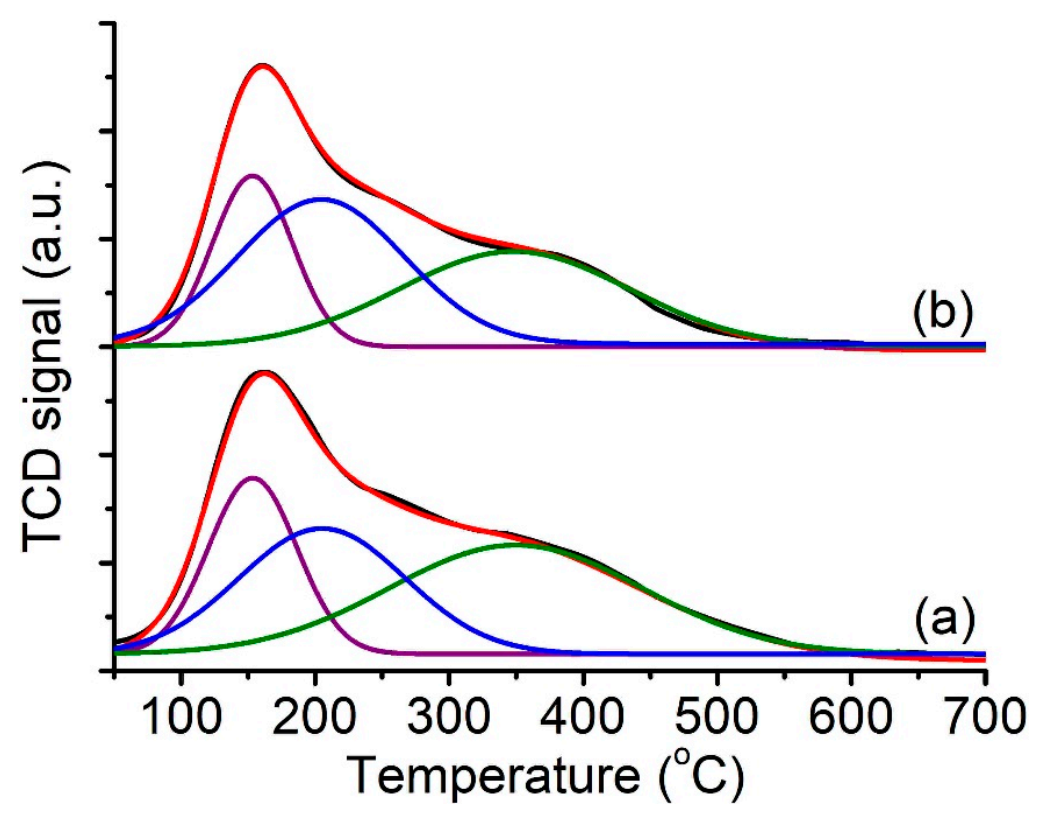

Figure 5. $\mathrm{NH}_{3}$-TPD profiles of (a) $\mathrm{CTA}^{+}$-offretite and (b) $\mathrm{TMA}^{+}$-offretite zeolites after deconvolution, which shows the presence of weak, mild, and strong acid sites.

The acid properties of $\mathrm{CTA}^{+}$-offretite were tested in the acylation of 2-methylfuran under novel non-microwave instant heating condition $\left(170{ }^{\circ} \mathrm{C}, 40 \mathrm{~min}\right)$ where the desired product 2-acetyl-5-methylfuran was obtained, which is a useful biofuel additive. The conversion was very low (12\%) when no catalyst was added, indicating that acylation of 2-methylfuran is an activated reaction and, hence, requires a catalyst to overcome the activation energy [33] (Table 2, Entry 1). When hierarchical CTA ${ }^{+}$-offretite was added, the conversion increased tremendously to $83.5 \%$ with $100 \%$ selectivity towards 2 -acetyl5-methylfuran (molecular size $6.6 \times 4.1 \AA^{2}$ [30]) (Entry 2). The catalytic performance of $\mathrm{CTA}^{+}$-offretite was also compared with that of the classical $\mathrm{TMA}^{+}$-offretite under the same reaction conditions. As expected, when using $\mathrm{CTA}^{+}$-offretite, the reaction conversion $(83.5 \%)$ was higher than that of the $\mathrm{TMA}^{+}$-counterpart $(78.3 \%)$ due to its larger surface acidity and the higher accessibility of the acid sites (Entry 4). Thus, the data shows the importance of hierarchical porosity for enhanced bulk molecule diffusivity and accessibility.

The catalytic activity of $\mathrm{CTA}^{+}$-offretite was also compared with those of the conventional homogeneous catalysts (e.g., $\mathrm{HCl}, \mathrm{HNO}_{3}, \mathrm{CH}_{3} \mathrm{COOH}$ ). The results showed that $\mathrm{CTA}^{+}$-offretite had comparable catalytic activity to the $\mathrm{HNO}_{3}(83.6 \%$ conversion), and it exhibited even better catalytic activity than the $\mathrm{HCl}(72.3 \%)$ and the $\mathrm{CH}_{3} \mathrm{COOH}(47.1 \%)$ after 40 min of reaction (Entries 5-7). Most importantly, the CTA ${ }^{+}$-offretite showed high stability, and no significant loss in catalytic reactivity of the catalyst was observed, even after five consecutive runs (Entry 3). Thus, the strategy of synthesizing offretite zeolite with hierarchical structure by amphiphile-templating synthesis route can be considered as safer, cheaper, facile, and scalable compared to the previous works [34]. 
Table 2. Catalytic performance of offretite catalysts in acylation of 2-methylfuran at $170{ }^{\circ} \mathrm{C}$ under non-microwave instant heating conditions.

\begin{tabular}{|c|c|c|c|c|}
\hline \multirow{2}{*}{ Entry } & \multirow{2}{*}{ Catalysts } & \multicolumn{3}{|c|}{ Conversion (\%) } \\
\hline & & $10 \mathrm{~min}$ & $20 \mathrm{~min}$ & $40 \mathrm{~min}$ \\
\hline 1 & No catalyst & 3.2 & 6.4 & 12.0 \\
\hline 2 & $\mathrm{CTA}^{+}$-offretite & 52.6 & 72.3 & 83.5 \\
\hline 3 & $\mathrm{CTA}^{+}$-offretite ${ }^{\mathrm{a}}$ & 50.2 & 68.0 & 79.1 \\
\hline 4 & $\mathrm{TMA}^{+}$-offretite & 44.7 & 61.7 & 78.3 \\
\hline 5 & $\mathrm{HCl}$ & 35.7 & 55.3 & 72.3 \\
\hline 6 & $\mathrm{HNO}_{3}$ & 51.1 & 71.9 & 83.6 \\
\hline 7 & $\mathrm{CH}_{3} \mathrm{COOH}$ & 16.0 & 31.9 & 47.1 \\
\hline
\end{tabular}

a after fifth run.

\section{Materials and Methods}

\subsection{Chemicals and Materials}

Potassium hydroxide pellets ( $\mathrm{KOH}, 85 \%)$, ammonium nitrate $\left(\mathrm{NH}_{4} \mathrm{NO}_{3}, 95 \%\right)$, nitric acid $\left(\mathrm{HNO}_{3}, 67 \%\right)$, 2-methylfuran (99\%), acetic anhydride (98.5\%), diethyl ether $(99 \%)$, and tetramethylammonium salt (TMACl) were purchased from Merck (Darmstadt, Germany). Aluminum sulfate hexadecahydrate $\left(\mathrm{Al}_{2}\left(\mathrm{SO}_{4}\right)_{3} \cdot 16 \mathrm{H}_{2} \mathrm{O}, 97 \%\right)$ was obtained from $\mathrm{BDH}$ Chemical Ltd. (Poole, England). Colloidal silica HS-40 was supplied by Sigma-Aldrich (Darmstadt, Germany). Glacial acetic acid $\left(\mathrm{CH}_{3} \mathrm{COOH}, 99 \%\right)$ and hydrochloric acid $(\mathrm{HCl}$, 37\%) were purchased from Qrëc (Asia) Sdn. Bhd (Rawang, Malaysia). Cetyltrimethylammonium bromide (CTABr, 97\%) was procured from Acros Organics (Geel, Belgium). All chemicals were used without further purification.

\subsection{Synthesis of $C T A^{+}$-Offretite Zeolite}

A clear aluminate solution was first prepared by dissolving $\mathrm{KOH}(3.018 \mathrm{~g})$, $\mathrm{Al}_{2}\left(\mathrm{SO}_{4}\right)_{3} \cdot 16 \mathrm{H}_{2} \mathrm{O}(1.442 \mathrm{~g})$, and CTABr $(1.221 \mathrm{~g})$ in distilled water $(18.208 \mathrm{~g})$. A clear silicate solution was then prepared by mixing HS-40 (6.875 g) with distilled water $(9.958 \mathrm{~g})$. A hydrogel with a final molar ratio of $20 \mathrm{SiO}_{2}: 1 \mathrm{Al}_{2} \mathrm{O}_{3}: 10 \mathrm{~K}_{2} \mathrm{O}: 1.46 \mathrm{CTABr}: 800 \mathrm{H}_{2} \mathrm{O}$ was formed after mixing the silicate and aluminate solutions and subjected to aging under stirring $\left(18 \mathrm{~h}, 25^{\circ} \mathrm{C}, 500 \mathrm{rpm}\right)$ and crystallization $\left(180^{\circ} \mathrm{C}, 72 \mathrm{~h}\right)$. The solid product was filtered, purified with distilled water until a $\mathrm{pH}$ of 7 , and calcined at $550{ }^{\circ} \mathrm{C}$ for $6 \mathrm{~h}$. Then, the obtained solid ( $3.000 \mathrm{~g})$ was further ion-exchanged with $\mathrm{NH}_{4} \mathrm{NO}_{3}$ solution $(1 \mathrm{M})$ and calcined $\left(500{ }^{\circ} \mathrm{C}, 4 \mathrm{~h}\right)$ to produce protonated offretite zeolite. For comparison, classical $\mathrm{TMA}^{+}$-offretite zeolite was synthesized using tetramethylammonium salt (TMACl) as an SDA [35], and the protonated form zeolite was prepared using the same protocol.

\subsection{Characterization}

The XRD patterns were recorded with a PANalytical X'Pert PRO diffractometer (Malvern Panalytical Ltd, Malvern, United Kingdom) $(\mathrm{Cu} \mathrm{K} \alpha$ radiation, $\lambda=0.15418 \mathrm{~nm}$, $40 \mathrm{kV}, 10 \mathrm{~mA}$, step size $=0.02^{\circ}$, scan speed $=0.2^{\circ} / \mathrm{min}$, scanning range $2 \theta=3^{\circ}-30^{\circ}$ ). The morphological properties of zeolite samples were studied using a JEOL JSM-6701F FESEM microscope (JEOL, Tokyo, Japan) operating at $20 \mathrm{kV}$. The chemical composition (Si/ Al ratio) of zeolite was estimated using the IR spectroscopy technique with a Perkin Elmer's System 2000 spectrometer (Perkin-Elmer, Waltham, MA, USA) [36]. The porous properties of solids were studied using a Micromeritics ASAP 2010 instrument (Micrometrics, Norcross, GA, USA). Prior to measurement, the powder sample (ca. $0.07 \mathrm{~g}$ ) was degassed at $300{ }^{\circ} \mathrm{C}$ for $12 \mathrm{~h}$ and the $\mathrm{N}_{2}$ adsorption was carried out at $-196{ }^{\circ} \mathrm{C}$. The total surface area was computed using the Brunauer-Emmett-Teller (BET) equation, whereas the external surface area and micropore volume were calculated using the t-plot model. The total pore volume of the samples was determined using the amount of $\mathrm{N}_{2}$ uptake at the relative pressure $\left(\mathrm{p} / \mathrm{p}^{\mathrm{o}}\right)$ of 0.996 . The acidity of samples was investigated with a BELCAT-B temperature programmed desorption (TPD) instrument (MicrotracBEL, Osaka, Japan). First, the powder 
sample (ca. $0.07 \mathrm{~g}$ ) was outgassed at $400{ }^{\circ} \mathrm{C}$ overnight before the cell was saturated with $\mathrm{NH}_{3}$ gas at $25^{\circ} \mathrm{C}$ for $30 \mathrm{~min}$. The non-adsorbed $\mathrm{NH}_{3}$ was then evacuated before the sample was heated and desorbed slowly from $25^{\circ} \mathrm{C}$ to $600{ }^{\circ} \mathrm{C}$ with a heating rate $10^{\circ} \mathrm{C} / \mathrm{min}$.

\subsection{Catalytic Test}

Offretite zeolite $\left(0.300 \mathrm{~g}, 400{ }^{\circ} \mathrm{C}, 4 \mathrm{~h}\right)$, 2-methylfuran $(4.7 \mathrm{mmol})$, and acetic anhydride (14.1 mmol) were first added into a 10-mL glass vial. The vial was inserted into a nonmicrowave instant heating reactor (Monowave 50) (Anton Paar Austria GmbH, Graz, Austria) and instantly heated to $170^{\circ} \mathrm{C}$ for $40 \mathrm{~min}$; less than $2 \mathrm{~min}$ was required to reach the desired temperature. After cooling, the reaction solution was isolated using microfiltration and analyzed with an Agilent's GCMS-5975 Turbo System and 7890A GC-FID (Santa Clara, SJ, USA).

\section{Conclusions}

In conclusion, offretite zeolite with high crystallinity has been synthesized via the amphiphile-templating approach. By using cetyltrimethylammonium bromide (CTABr) as a promising structure-directing agent (SDA), as its hydrophilic head has nearly the same dimensions as tetramethylammonium $\left(\mathrm{TMA}^{+}\right)$, offretite zeolite crystals with hexagonal prism shape $\left(10.8 \times 1.4 \mu \mathrm{m}^{2}\right)$ were crystallized at $180^{\circ} \mathrm{C}$ for $72 \mathrm{~h}$. The resulting offretite zeolite had larger surface areas, pore volume, and pore sizes due to the use of $\mathrm{CTA}^{+}$, which also served as a mesoporogen. Furthermore, $\mathrm{CTA}^{+}$-offretite $(0.74 \mathrm{mmol} / \mathrm{g})$ had higher acidity than the conventional $\mathrm{TMA}^{+}$-offretite $(0.68 \mathrm{mmol} / \mathrm{g})$, and its acidity and accessible porosity were highly needed in the acylation of 2-methylfuran: $83.5 \%$ conversion and $100 \%$ selectivity to the desired product after $40 \mathrm{~min}$ reaction at $170{ }^{\circ} \mathrm{C}$ under non-microwave instant heating conditions were recorded. Most importantly, the $\mathrm{CTA}^{+}$-offretite catalyst was stable, fully recoverable, and more active than the conventional $\mathrm{TMA}^{+}$-offretite and other homogeneous acid catalysts, including $\mathrm{HCl}, \mathrm{HNO}_{3}$, and $\mathrm{CH}_{3} \mathrm{COOH}$. In short, the amphiphile-templating strategy can be applied for the preparation of other important zeolites that are usually synthesized by harmful and expensive organic templates.

Author Contributions: N.H.A.: Visualization, investigation, formal analysis, validation, methodology; T.J.D.: resources, investigation, formal analysis, funding acquisition, writing - review and editing, conceptualization; F.K. and S.M.: writing-review and editing, investigation, T.-C.L.: funding acquisition, investigation; E.-P.N.: supervision, funding acquisition, writing-review and editing, investigation, conceptualization. All authors have read and agreed to the published version of the manuscript.

Funding: The financial support from RUI (1001/PKIMIA/8011128) and Institut Universitaire de France (IUF) is acknowledged.

Institutional Review Board Statement: Not applicable.

Informed Consent Statement: Not applicable.

Data Availability Statement: Not applicable.

Conflicts of Interest: The authors declare no conflict of interest. The funders had no role in the design of the study; in the collection, analyses, or interpretation of data; in the writing of the manuscript, or in the decision to publish the results.

Sample Availability: The samples are available from N.H.A and E.-P.N.

\section{References}

1. Dusselier, M.; Davis, M.E. Small-Pore Zeolites: Synthesis and Catalysis. Chem. Rev. 2018, 118, 5265-5329. [CrossRef]

2. Wong, S.-F.; Deekomwong, K.; Wittayakun, J.; Ling, T.C.; Muraza, O.; Adam, F.; Ng, E.-P. Crystal growth study of KF nanozeolite and its catalytic behavior in Aldol condensation of benzaldehyde and heptanal enhanced by microwave heating. Mater. Chem. Phys. 2017, 196, 295-301. [CrossRef] 
3. Liu, J.; Luo, W.; Cao, H.; Weng, L.; Feng, G.; Fu, X.-Z.; Luo, J.-L. Understanding the immobilization mechanisms of hazardous heavy metal ions in the cage of solidate at molecular level: A DTF study. Microporous Mesoporous Mater. 2020, $306,110409$. [CrossRef]

4. Tan, K.-H.; Awala, H.; Mukti, R.R.; Wong, K.-L.; Ling, T.C.; Mintova, S.; Ng, E.-P.; Taiwan, J. Zeolite nanoparticles as effective antioxidant additive for the preservation of palm oil-based lubricant. Inst. Chem. Eng. 2016, 58, 565-571. [CrossRef]

5. International Zeolite Association. Available online: http://www.iza-online.org/ (accessed on 21 March 2021).

6. Catizzone, E.; Migliori, M.; Mineva, T.; van Daele, S.; Valtchev, V.; Girodano, G. New synthesis routes and catalytic applications of ferrierite crystals. Part 2:1,8-Diaminooctane as a new OSDA. Microporous Mesoporous Mater. 2020, 296, 109987. [CrossRef]

7. Tosheva, L.; Ng, E.-P.; Mintova, S.; Hölzl, M.; Metzger, T.H.; Doyle, A.M. AlPO $4-18$ Seed Layers and Films by Secondary Growth Chem. Mater. 2008, 20, 5721-5726. [CrossRef]

8. Wang, Y.; Wu, Q.; Meng, X.; Xiao, F.-S. Insights into the Organotemplate-Free Synthesis of Zeolite Catalysts. Engineering 2017, 3, 567-574. [CrossRef]

9. Ng, E.-P.; Awala, H.; Ghoy, J.-P.; Vicente, A.; Ling, T.C.; Ng, Y.H.; Mintova, S.; Adam, F. Effects if ultrasonic irradiation on crystallization and structural properties of EMT-tyoe zeolite nanocrystals. Mater. Chem. Phys. 2015, 159, 38-45. [CrossRef]

10. Khoo, D.Y.; Kok, W.-M.; Mukti, R.R.; Mintova, S.; Ng, E.-P. Ionothermal approach for synthesizing AlPO-5 with hexagonal thin-plate morphology influenced by various parameters at ambient pressure. Solid State Sci. 2013, 25, 63-69. [CrossRef]

11. Ng, E.-P.; Itani, L.; Sekhon, S.S.; Mintova, S. Micro- to Macroscopic Observations of MnAlPO-5 Nanocrystal Growth in Ionic-Liquid Media. Chem. Eur. J. 2010, 16, 12890-12897. [CrossRef] [PubMed]

12. Itakuram, M.; Ota, K.; Shibata, S.; Inoue, T.; Ide, Y.; Sadakane, M.; Sano, T. Influence of starting zeolite on synthesis of RUT type zeolite by interzeolite conversion method. J. Cryst. Growth 2011, 314, 274-278. [CrossRef]

13. Boruntea, C.-R.; Lundegaard, L.F.; Corma, A.; Vennestrom, P.N.R. Crystallization of AEI and AFX zeolites through zeolite-tozeolite transformations. Microporous Mesoporous Mater. 2019, 278, 105-114. [CrossRef]

14. Trachta, M.; Nachtigall, P.; Bludsky, O. The ADOR synthesis of new zeolites: In silico investigation. Catal. Today 2015, 243, 32-38. [CrossRef]

15. Prech, J.; Cejka, J. UTL titanosilicate: An extra-large pore epoxidation catalyst with tunable textural properties. Catal. Today 2016, 277, 2-8. [CrossRef]

16. Caullet, P.; Paillaud, J.-L.; Masseron, A.S.; Soulard, M.; Patarin, J. The fluoride route: A strategy to crystalline porous materials. CR Chim. 2005, 8, 245-266. [CrossRef]

17. Matijasic, A.; Gramlich, V.; Patarin, J. Mu-17: A new member of the gallophosphate family prepared by the fluoride route. Solid State Sci. 2001, 3, 155-167. [CrossRef]

18. Gard, J.A.; Tait, J.M. The crystal structure of the zeolite offretite, $\mathrm{K}_{1.1} \mathrm{Ca}_{1.1} \mathrm{Mg}_{0.7}\left[\mathrm{Si}_{12.8} \mathrm{Al}_{5.2} \mathrm{O}_{36}\right] .15 .2 \mathrm{H}_{2} \mathrm{O}$. Acta Cryst. 1972, B28, 825-834. [CrossRef]

19. Lukaszuk, K.A.; Gama, D.R.; Odegaard, S.O.; Lazzarini, A.; Berlier, G.; Bordiga, S.; Lillerud, K.P.; Olsbye, U.; Beato, P.; Lundegaard, L.F.; et al. Zeolite morphology and catalyst performance: Conversion of methanol to hydrocarbons over offretite. Catal. Sci. Technol. 2017, 7, 5435-5447. [CrossRef]

20. Sanyuan, Y.; Evmiridis, N.P. Synthesis and characterization of an offretite/erionite type zeolite. Micropor. Mater. 1996, 6, 19-26.

21. Gao, F.; Li, X.; Zhu, G.; Qui, S.; Wei, B.; Shao, C.; Terasaki, O. The synthesis of offretite single crystals in the system containing pyrocatechol or $\mathrm{F}^{-}$. Mater. Lett. 2001, 48, 1-7. [CrossRef]

22. Matijasic, A.; Patarin, J. Synthesis of OFF-type zeolite in a quasi non aqueous medium: Structure directing role of $p$-dioxane and alkaline cations. Microporous Mesoporous Mater. 1999, 29, 405-412. [CrossRef]

23. Itakura, M.; Oumi, Y.; Sadakane, M.; Sano, T. Synthesis of high-silica offretite by the interzeolite conversion method. Mater. Res. Bull. 2020, 45, 646-650. [CrossRef]

24. Kresge, C.T.; Leonowicz, M.E.; Roth, W.J.; Vartuli, J.C.; Beck, J.S. Ordered mesoporous molecular sieves synthesized by a liquid-crystal template mechanism. Nature 1992, 359, 710-712. [CrossRef]

25. Adam, F.; Appaturi, J.N.; Ng, E.-P. Halide aided synergistic ring opening mechanism of epoxides and their cycloaddition to $\mathrm{CO}_{2}$ using MSM-41-imidazolium bromide catalyst. J. Mol. Catal. A Chem. 2014, 386, 42-48. [CrossRef]

26. Chen, H.; Fu, S.; Fu, L.; Yang, H.; Chen, D. Simple Synthesis and Characterization of Hexagonal and Ordered Al-MCM-41 from Natural Perlite. Minerals 2019, 9, 264. [CrossRef]

27. Wang, X.; Karakilic, P.; Liu, X.; Shan, M.; Nijmeijer, A.; Winnubst, L.; Gascon, J.; Kapteign, F. One-Pot Synthesis of High-Flux $b$-Oriented MFI Zeolite Membranes for Xe Recovery. ACS Appl. Mater. Interfaces 2018, 10, 33574-33580. [CrossRef] [PubMed]

28. Wong, S.-F.; Awala, H.; Vincente, A.; Retoux, R.; Ling, T.C.; Mintova, S.; Mukti, R.R.; Ng, E.-P. K-F zeolite nanocrystals synthesized from organic-template-free precursor mixture. Microporous Mesoporous Mater. 2017, 249, 105-110. [CrossRef]

29. Ng, E.-P.; Delmotte, L.; Mintova, S. Environmentally benign synthesis of nanosized aluminophosphate enhanced by microwave heating. Green Chem. 2008, 10, 1043-1048. [CrossRef]

30. The Molecular Sizes of the Compounds Were Estimated Using HyperChem ${ }^{\mathrm{TM}}$-Release 8.0 for Windows Molecular Modeling System; Hypercube, Inc.: Gainesville, FL, USA, 2011.

31. Ali, D.; Zeiger, C.R.; Azim, M.M.; Lein, H.L.; Mathisen, K. Evaluation of surfactant templates for one-pot hydrothermal synthesis of hierarchical SAPO-5. Microporous Mesoporous Mater. 2020, 306, 110364. [CrossRef] 
32. Přech, J.; Bozhilov, K.N.; Fallah, J.E.; Barrier, N.; Valtchev, V. Fluoride etching opens the structure and strengthens the active sites of the layered ZSM-5 zeolite. Microporous Mesoporous Mater. 2019, 280, 297-305. [CrossRef]

33. Ghrear, T.M.A.; Rigolet, S.; Daou, T.J.; Mintova, S.; Ling, T.C.; Tan, S.H.; Ng, E.P. Synthesis of Cs-ABW nanozeolite in organotemplate-free system. Microporous Mesoporous Mater. 2019, 227, 78-83. [CrossRef]

34. Serrano, D.P.; Escola, J.M.; Pizarro, P. Synthesis strategies in the search for hierarchical zeolites. Chem. Soc. Rev. 2013, 42, 4004-4035. [CrossRef] [PubMed]

35. Mintova, S. Verified Syntheses of Zeolitic Materials, 3rd ed.; Elsevier Science: Amsterdam, The Netherlands, 2016.

36. Ma, Y.-K.; Rigolet, S.; Michelin, L.; Paillaud, J.L.; Mintova, S.; Khoerunnisa, F.; Daou, T.J.; Ng, E.-P. Facile and fast determination of $\mathrm{Si} / \mathrm{Al}$ ratio of zeolites using FTIR spectroscopy technique. Microporous Mesoporous Mater. 2021, 311, 110683. [CrossRef] 